\title{
Thymoma and Autoimmune Encephalitis
}

\section{Clinical Manifestations and Antibodies}

\author{
Mar Guasp, MD, * Jon Landa, MSc, * Eugenia Martinez-Hernandez, MD, PhD, Lidia Sabater, PhD, \\ Takahiro lizuka, MD, Mateus Simabukuro, MD, PhD, Masataka Nakamura, MD, PhD, \\ Makoto Kinoshita, MD, PhD, Masanori Kurihara, MD, Kenichi Kaida, MD, PhD, Jordi Bruna, MD, PhD, \\ Solange Kapetanovic, MD, PhD, Pedro Sánchez, MD, Raquel Ruiz-García, PhD, Laura Naranjo, BSc, \\ Jesús Planagumà, PhD, Amaia Muñoz-Lopetegi, MD, Luis Bataller, MD, PhD, Albert Saiz, MD, PhD, \\ Josep Dalmau, MD, PhD, $†$ and Francesc Graus, MD, PhD†
}

Neurol Neuroimmunol Neuroinflamm 2021;8:e1053. doi:10.1212/NXI.0000000000001053

\author{
Correspondence \\ Dr. Graus \\ francesc.graus@idibaps.org
}

\begin{abstract}
\section{Objective}

To report the clinical, neuroimaging, and antibody associations in patients with autoimmune encephalitis $(\mathrm{AE})$ and thymoma.
\end{abstract}

\section{Methods}

A retrospective cohort study of 43 patients was conducted. Antibody determination and immunoprecipitation to characterize novel antigens were performed using reported techniques.

\section{Results}

Patients' median age was 52 years (range: $23-88$ years). Forty (93\%) had neuronal surface antibodies: gamma-aminobutyric acid receptor $\mathrm{A}\left(\mathrm{GABA}_{\mathrm{A}} \mathrm{R}\right)$ (15), amino-3-hydroxy-5methyl-4-isoxazolepropionic acid receptor (AMPAR) (13), contactin-associated protein-like 2 (CASPR2) (4), leucine-rich, glioma inactivated 1 (LGI1) (3), glycine receptor (GlyR) (3), and unknown antigens (2). Concurrent antibodies against intracellular antigens occurred in 13 (30\%; 9 anti-collapsin response mediator protein 5 [CRMP5]) and were more frequent in antiAMPAR encephalitis $(54 \%$ vs $20 \% ; p=0.037)$. The most common clinical presentation was encephalitis with multiple $\mathrm{T} 2$ /fluid-attenuated inversion recovery hyperintense lesions in 23 (53\%) patients (15 GABA $\mathrm{A}, 5$ AMPAR, and 1 unknown neuropil antibody), followed by encephalitis with peripheral nerve hyperexcitability in 7 (16\%; 4 CASPR2, 2 LGI1, and 1 unknown antibody), limbic encephalitis in 6 (14\%; 4 AMPAR, 1 LGI1, and 1 antibody negative), progressive encephalomyelitis with rigidity and myoclonus in 4 (9\%; 3 GlyR and 1 AMPAR antibodies), and encephalitis with normal MRI in 3 (7\%; AMPAR antibodies). Anti$\mathrm{GABA}_{\mathrm{A}} \mathrm{R}$ encephalitis was more prevalent in Japanese patients compared with Caucasians and other ethnicities $(61 \%$ vs $16 \% ; p=0.003)$. In anti-AMPAR encephalitis, $3 / 4$ patients with poor and $0 / 6$ with good outcome had concurrent CRMP5 antibodies $(p=0.033)$. Immunoprecipitation studies identified metabotropic glutamate receptor 3 antibodies that were additionally found in 5 patients ( 3 with and 2 without encephalitis).

\footnotetext{
*These authors contributed equally to this work as co-first authors.
}

tThese authors contributed equally to this work as co-senior authors.

From the Institut d'Investigacions Biomèdiques August Pi i Sunyer (IDIBAPS) (M.G., J.L., E.M.-H., L.S., J.P., A.M.-L., A.S., J.D., F.G.), Hospital Clínic, Universitat de Barcelona; Neurology Department (M.G., E.M.-H., A.M.-L., A.S., J.D.), Institute of Neuroscience, Hospital Clínic, Barcelona; Centro de Investigación Biomédica en Red (M.G., E.M.-H., L.S., J.D.), Enfermedades Raras (CIBERER), Spain; Department of Neurology (T.I.), Kitasato University School of Medicine, Sagamihara, Japan; Neurology Division (M.S.), University of São Paulo, School of Medicine, Brazil; Department of Neurology (M.N.), Kansai Medical University, Hirakata; Department of Neurology (M. Kinoshita), Osaka University Graduate School of Medicine; Department of Neurology (M. Kurihara), Graduate School of Medicine, University of Tokyo; Department of Neurology (K.K.), Saitama Medical Center, Saitama Medical University, Kawagoe, Japan; Neuro-Oncology Unit (J.B.), Hospital Universitari de Bellvitge-ICO L'Hospitalet, Spain; Department of Neurology (S.K.), Hospital de Basurto, Bilbao; Hospital Universitario de La Princesa (P.S.), Instituto de Investigación Sanitaria La Princesa, Madrid; Immunology Department (R.R.-G., L.N.), Centre Diagnòstic Biomèdic, Hospital Clínic, Barcelona; Neurology Department (L.B.), Hospital Universitari i Politècnic La Fe, Valencia, Spain; Department of Neurology (J.D.), Perelman School of Medicine, University of Pennsylvania, Philadelphia; and Catalan Institute for Research and Advanced Studies (ICREA) (J.D.), Barcelona, Spain.

Go to Neurology.org/NN for full disclosures. Funding information is provided at the end of the article. 


\section{Glossary}

AE = autoimmune encephalitis; AMPAR = amino-3-hydroxy-5-methyl-4-isoxazolepropionic acid receptor; CASPR2 = contactin-associated protein-like 2; CBA = cell-based assay; CRMP5 = collapsin response mediator protein 5; FLAIR = fluidattenuated inversion recovery; $\mathbf{G A B A}_{\mathbf{A}} \mathbf{R}=$ gamma-aminobutyric acid receptor $\mathbf{A} ; \mathbf{G A B A}_{\mathbf{B}} \mathbf{R}=$ gamma-aminobutyric acid receptor B; GAD = glutamic acid decarboxylase; GlyR = glycine receptor; HEK = human embryonic kidney; HLA = human leukocyte antigen; IgLON5 = immunoglobulin-like cell adhesion molecule 5; LGI1 = leucine-rich, glioma inactivated 1; MG = myasthenia gravis; $\mathbf{m G l u R}=$ metabotropic glutamate receptor; $\mathbf{m R S}=$ modified Rankin Scale; PERM $=$ progressive encephalomyelitis with rigidity and myoclonus; $\mathbf{P N H}=$ peripheral nerve hyperexcitability.

\section{Conclusions}

$\mathrm{AE}$ in patients with thymoma include several clinical-radiologic syndromes that vary according to the associated antibodies. Anti$\mathrm{GABA}_{\mathrm{A}} \mathrm{R}$ encephalitis was the most frequent $\mathrm{AE}$ and occurred more frequently in Japanese patients.

Thymomas frequently associate with systemic and neurologic autoimmune disorders, mainly myasthenia gravis (MG). ${ }^{1,2}$ Although these disorders can be considered paraneoplastic, there are some features that differentiate them from classical paraneoplastic neurologic syndromes. First, the autoimmune neurologic syndromes associated with thymoma occur more frequently as non-paraneoplastic syndromes. For example, in MG, only $15 \%-20 \%$ of patients have an underlying thymoma. ${ }^{3}$ Second, with the exception of MG, up to $40 \%$ of the remaining autoimmune neurologic syndromes develop months to years after the diagnosis and treatment of the thymoma. ${ }^{4}$ Third, compared with other tumors, the higher frequency of autoimmune disorders in patients with thymoma suggests a loss of self-tolerance that normally occurs in the thymus, resulting in autoreactive $\mathrm{T}$ cells that also affect B-cell function. ${ }^{3,5}$ This mechanism is different from that proposed for classical paraneoplastic neurologic syndromes in which the immune response is likely triggered by tumor expression of the antigen. ${ }^{6}$

The occurrence of autoimmune encephalitis $(\mathrm{AE})$ in patients with thymoma was first recognized in $1988,{ }^{7}$ and since then, around 40 cases have been reported, showing a great heterogeneity in clinical and brain MRI features, as well as in the antibody repertoire. ${ }^{8}$ Previous series on thymomas and autoimmune neurologic disorders focused on the analysis of neuronal antibody profiles in patients with multiple neurologic manifestations. ${ }^{9,10}$ Moreover, the frequency and distribution of the most recently characterized neuronal surface antibodies have not been previously described in a well clinically defined series of patients with $\mathrm{AE}$ with thymomas. ${ }^{11}$

Here, we describe the spectrum of clinical and neuroimaging features in patients with $\mathrm{AE}$ with thymoma and the associated neuronal antibodies.

\section{Methods}

\section{Patients, Controls, and Clinical Definitions}

We retrospectively assessed the clinical information of patients with suspected $\mathrm{AE}$ and histologic diagnosis of thymoma whose serum or CSF samples were sent to the Neuroimmunology Laboratory of the Institute of Biomedical Research August Pi i Sunyer, Hospital Clínic, for determination of neuronal antibodies, between January 2000 and October 2020. Demographic and clinical data were obtained by review of clinical records, and a structured written questionnaire was sent to the referring physicians. Patients were included in the study if they had clinical manifestations compatible with $\mathrm{AE}^{12}$ and serum or CSF was available for immunologic studies.

The encephalitis was classified into 5 groups: (1) limbic encephalitis with MRI T2-weighted/fluid-attenuated inversion recovery (FLAIR) hyperintense lesions highly restricted to medial temporal lobes ${ }^{12}$; (2) encephalitis with concomitant peripheral nerve hyperexcitability $(\mathrm{PNH})^{13}$; $(3)$ encephalitis and multiple T2/FLAIR hyperintense lesions in the cerebral hemispheres or basal ganglia; (4) encephalitis with normal brain MRI; and (5) encephalitis with prominent brainstem symptoms and rigidity compatible with the diagnosis of progressive encephalomyelitis with rigidity and myoclonus (PERM). ${ }^{14}$

In patients with multiple neuronal surface antibodies, a predominant antibody was chosen on the basis of its presence in the CSF, titers, and type of AE. Controls for antibody studies included paired serum/CSF (23) or serum (16) samples of 39 patients with thymoma and isolated neuromuscular disorders (23 with MG, 1 of them with concomitant optic neuritis, and 16 with $\mathrm{PNH}$ ).

\section{Antibody Studies}

Samples were investigated for cell surface, synaptic, and onconeural antibodies by immunohistochemistry and inhouse cell-based assays (CBAs). Rat brain immunostaining was performed with patients' serum and CSF using a standard avidin-biotin immunoperoxidase technique adapted to cell surface and intracellular antibodies, as reported. ${ }^{15,16}$ The presence of antibodies against amino-3-hydroxy-5-methyl-4-isoxazolepropionic acid receptor (AMPAR), aquaporin 4, contactin-associated protein-like 2 (CASPR2), dipeptidyl-peptidase-like protein 6 , 
gamma-aminobutyric acid receptors $\mathrm{A}\left(\mathrm{GABA}_{\mathrm{A}} \mathrm{R}\right)$ and $\mathrm{B}$ $\left(\mathrm{GABA}_{\mathrm{B}} \mathrm{R}\right)$, glycine receptor (GlyR), immunoglobulin-like cell adhesion molecule 5 (IgLON5), leucine-rich, glioma inactivated 1 (LGI1), metabotropic glutamate receptor 1 (mGluR1), 2 (mGluR2), 3 (mGluR3), and 5 (mGluR5), neurexin $3 \alpha$, and NMDA receptor was determined with in-house CBAs with live (serum 1:50 and CSF 1:5) or fixed (serum 1:40 and CSF 1:2) human embryonic kidney (HEK)-293 cells expressing the corresponding aforementioned antigens, as reported. ${ }^{17}$ The commercial immunoblot kit EUROLINE Paraneoplastic Neurological Syndromes 12 Ag (DL 1111-1601-7 G; Euroimmun, Lübeck, Germany) was used following the manufacturers' instructions to confirm glutamic acid decarboxylase (GAD) and onconeural reactivities seen in the immunohistochemistry studies. Immunoprecipitation using cultures of rat cerebellar granule neurons and patient's serum was used to characterize the target antigen in a patient who had antibodies against an unknown cell surface protein, as described. ${ }^{17}$ The serum of this patient was preabsorbed with HEK293-mGluR3 cells and tested on rat brain sections to determine whether the preabsorption prevented brain immunoreactivity. The immunoabsorption studies were conducted as previously reported. ${ }^{18}$

\section{Statistical Analysis}

Variables comparing patients with thymoma-associated AE and isolated neuromuscular disorders were analyzed with the Fisher exact test. All tests were 2 tailed, and statistical significance was set at $<0.05$. All analyses were performed with SPSS Statistics 26.0 (IBM, New York City, NY).

\section{Standard Protocol Approvals, Registrations, and Patient Consents}

The Ethic Committee of the Hospital Clinic approved the study. All patients or proxies gave written informed consent for the storage and use of serum, CSF, and clinical information for research purposes.

\section{Data Availability}

All data are reported within the article and available anonymized by request from qualified investigators.

\section{Results}

We identified 61 patients with thymoma and suspected AE, 18 of them were excluded due to inadequate clinical information or because an alternative diagnosis was established; 43 were lastly diagnosed with $\mathrm{AE}$ and included in the study. Eleven of them had been previously reported (including patients 5 and 6 of reference 15 , patients 13 and 15 of reference 19 , and patients 1 and 5 of reference 20). ${ }^{21-25}$ Median age of the 43 patients at disease onset was 52 years (range: $23-88$ years), and $26(60 \%)$ were female. Twenty (46\%) patients were Caucasian, 18 (42\%) Japanese, and 5 (12\%) had other ethnicities. Thirteen (30\%) patients had a previous diagnosis of $\mathrm{MG}$ with acetylcholine receptor antibodies. The thymoma was locally invasive or metastatic in 22 (51\%) patients and antedated the diagnosis of the encephalitis in 16
(37\%). In 7 (44\%) of them, the encephalitis coincided with oncological progression or relapse of the thymoma (Table 1). For the other patients in which the encephalitis preceded the tumor diagnosis, the thymoma was detected in the first tumor screening. The presence of MG or aggressive thymoma (invasive or metastatic) did not correlate with the type of encephalitis or associated neuronal antibodies. Long-term follow-up was available for 39 patients (median, 4 years; interquartile range: 10-68 months). Antibodies against neuronal surface antigens were found in 40 (93\%) of the 43 patients: $\mathrm{GABA}_{\mathrm{A}} \mathrm{R}$ in 15 patients, followed by AMPAR in 13, CASPR2 in 4, LGI1 in 3, GlyR in 3, and against unknown surface antigens in 2. Concurrent neuronal antibodies were detected in 16 (40\%) of 40 patients (Table 1 ). Two patients with AMPAR antibodies also had $\mathrm{GABA}_{\mathrm{B}} \mathrm{R}$ ( 1 of them along with CASPR2) antibodies; 3 patients, 2 with CASPR2 and 1 with $\mathrm{GABA}_{\mathrm{A}} \mathrm{R}$ antibodies, also had LGI1 antibodies. Concurrent antibodies against intracellular antigens were found in $13(30 \%)$ patients and included CRMP5 in 9 (21\%), GAD in $3(7 \%)$, and $\mathrm{Hu}$ in $1(2 \%)$ (Table 1). Onconeural and GAD antibodies were more commonly associated with AMPAR antibodies as they occurred in $7 / 13(54 \%)$ patients but in only $6 / 30(20 \%)$ without AMPAR antibodies $(p=0.037)$.

\section{Clinical Profiles of Thymoma-Associated Paraneoplastic Encephalitis}

The most common clinical presentation was encephalitis with multiple T2/FLAIR hyperintense lesions in 23 (53\%) patients; 15 of them had $\mathrm{GABA}_{\mathrm{A}} \mathrm{R}$ antibodies, 5 AMPAR antibodies, and 1 an unknown neuropil antibody. In 2 patients, no antibody was found, but CSF was not available in 1 of them (Figure 1). Encephalitis with multiple T2/FLAIR hyperintense lesions and $\mathrm{GABA}_{\mathrm{A}} \mathrm{R}$ antibodies was more prevalent in Japanese patients $(11 / 18,61 \%)$ than in patients of other ethnicities $(4 / 25,16 \% ; p$ $=0.003)$. Eleven $(73 \%)$ of the 15 patients with $\mathrm{GABA}_{\mathrm{A}} \mathrm{R}$ antibodies had prominent seizures that were the only symptom in 1 and evolved to refractory status epilepticus in 4 . Thirteen (87\%) of them had cognitive impairment and 11 (73\%) developed behavioral changes. CSF studies were normal in 13 (87\%) patients. The other 2 patients had mild clinical manifestations, although they had multiple lesions in the brain MRI. The brain MRI showed multiple non-contrast-enhancing bilateral T2/ FLAIR hyperintense lesions involving cortico-subcortical areas of both cerebral hemispheres (Figure 2, A and B). Follow-up MRI in $9(60 \%)$ patients showed the appearance of new lesions and improvement of others without a clear correlation with the use of immunotherapy. Although 10 (67\%) patients developed 1 or more relapses, 13 had good functional outcome (modified Rankin Scale $[\mathrm{mRS}]$ score $\leq 2$ ), including 1 who had full clinical and radiologic recovery without immunotherapy.

Another 5 patients with encephalitis and multiple T2/FLAIR hyperintense lesions had AMPAR antibodies (Table 1). Unlike patients with $\mathrm{GABA}_{\mathrm{A}} \mathrm{R}$ antibodies, CSF studies showed inflammatory signs in all (mean white blood cell count: 56; range: 7 to 164), and the T2/FLAIR hyperintense lesions involved the basal ganglia in 4 (80\%) patients, a feature only seen in 2 (13\%) patients with anti-GABA $A_{A} R$ encephalitis (Figure 1B). Three of 
Table 1 Clinical and Immunologic Features According to Neuronal Surface Antibody Type

\begin{tabular}{|c|c|c|c|c|c|c|c|}
\hline \multirow[b]{2}{*}{ Antibody } & \multirow[b]{2}{*}{$\begin{array}{l}\text { Japanese } \\
\text { ethnicity }\end{array}$} & \multirow[b]{2}{*}{$M^{a}{ }^{a}$} & \multirow[b]{2}{*}{$\begin{array}{l}\text { Aggressive } \\
\text { thymoma }\end{array}$} & \multirow[b]{2}{*}{$\begin{array}{l}\text { Type of encephalitis and MRI } \\
\text { features }\end{array}$} & \multicolumn{2}{|c|}{ Concurrent antibody } & \multirow[b]{2}{*}{$\begin{array}{l}\text { Good } \\
\text { outcome }\end{array}$} \\
\hline & & & & & $\begin{array}{l}\text { Neuronal } \\
\text { surface }\end{array}$ & Intracellular & \\
\hline $\mathrm{GABA}_{\mathrm{A}} \mathrm{R} 15$ (35) & $11(73)$ & $3(20)$ & $9(60)$ & $\begin{array}{l}\text { Multifocal T2/FLAIR lesions: } 15 \\
(100)\end{array}$ & LGI1: $1(7)^{c}$ & CRMP5: 1 (7) & $13(87)$ \\
\hline AMPAR $13(30)$ & $2(15)$ & $3(23)$ & $6(46)$ & $\begin{array}{l}\text { Multifocal T2/FLAIR lesions: } 5 \text { (38) } \\
\text { Limbic encephalitis: } 4 \text { (31) } \\
\text { With normal MRI: } 3 \text { (23) } \\
\text { PERM: } 1 \text { (8) }\end{array}$ & $\begin{array}{l}\text { GABA }_{B} R: 2(15)^{d} \\
\text { CASPR2: } 1(8)^{d}\end{array}$ & $\begin{array}{l}\text { CRMP5: } 4 \\
\text { (31) } \\
\text { GAD: } 2 \text { (15) } \\
\text { Hu: } 1 \text { (8) }\end{array}$ & $6 / 10(60)$ \\
\hline CASPR2 4 (9) & $0(0)$ & $3(75)$ & $4(100)$ & Encephalitis and PNH: 4 (100) & LGI1: $2(50)^{d}$ & $\begin{array}{l}\text { CRMP5: } 1 \\
(25)\end{array}$ & $1 / 3$ \\
\hline GlyR 3 (7) & $2(67)$ & $2(67)$ & $1(33)$ & PERM, 3 (100) & $0(0)$ & $\begin{array}{l}\text { CRMP5: } 1 \\
\text { (33) } \\
\text { GAD: } 1 \text { (33) }\end{array}$ & 3 \\
\hline LGI1 3 (7) & $3(100)$ & $1(33)$ & $2(67)$ & $\begin{array}{l}\text { Encephalitis and PNH: } 2 \text { (67) } \\
\text { Limbic encephalitis: } 1 \text { (33) }\end{array}$ & $0(0)$ & $0(0)$ & 0 \\
\hline Negative 3 (7) & $0(0)$ & $0(0)$ & $0(0)$ & $\begin{array}{l}\text { Multifocal T2/FLAIR lesions: } 2 \text { (67) } \\
\text { Limbic encephalitis: } 1 \text { (33) }\end{array}$ & $0(0)$ & $0(0)$ & 1 \\
\hline Unknown 2 (5) & $0(0)$ & $1(50)$ & $1(50)$ & $\begin{array}{l}\text { Encephalitis and PNH: } 1(50) \\
\text { With multifocal T2 lesions: } 1 \text { (50) }\end{array}$ & $0(0)$ & $\begin{array}{l}\text { CRMP5: } 2 \\
(100)\end{array}$ & 1 \\
\hline
\end{tabular}

Abbreviations: AMPAR = amino-3-hydroxy-5-methyl-4-isoxazolepropionic acid receptor; CASPR2 = contactin-associated protein-like 2; CRMP5 = collapsin response mediator protein 5; FLAIR = fluid-attenuated inversion recovery; GABA $A$ = gamma-aminobutyric acid receptor $A ; G A D=$ glutamic acid decarboxylase; GlyR = glycine receptor; IQR = interquartile range; LGI1 = leucine-rich glioma inactivated 1; MG = myasthenia gravis; PERM = progressive encephalomyelitis with rigidity and myoclonus; $\mathrm{PNH}=$ peripheral nerve hyperexcitability.

Data expressed as absolute numbers (\%).

${ }^{a}$ Median time between onset of MG and encephalitis was 18 months (IQR 12-96; range 3-204 months). Nine patients were on low-dose oral steroids, 1 oral

steroids + tacrolimus, 2 azathioprine, and 1 mycophenolate.

${ }^{\mathrm{b}}$ Locally invasive or metastatic.

' Only in CSF, low titer.

d Only in serum, low titer.

e Defined by modified Rankin Scale score $\leq 2$.

the 5 patients had a good response to immunotherapy, and despite a relapse in 2 , the $\mathrm{mRS}$ score was $\leq 2$ at the last visit.

Seven (16\%) of 43 patients developed encephalitis with concomitant PNH (Table 1). Four of them had serum and CSF CASPR2 antibodies, along with low serum titers of LGI1 antibodies in 2, 2 had LGI1 antibodies only, and 1 had an antibody against an unknown antigen. In contrast with the other clinical groups, all of these patients reported prominent sleep disorders. CSF studies were normal in all (only mildly increased protein concentration in 1). The 2 with LGI1 antibodies had hyponatremia and bilateral medial temporal lobe T2/FLAIR hyperintensities, whereas the 4 patients with CASPR 2 antibodies had a normal brain MRI. Two of the patients with concurrent CASPR2 and LGI antibodies and another 2 with isolated LGI1 antibodies had an unfavorable clinical course, and 3 of them died despite receiving immunotherapy. The fourth patient in this group was a 68 -year-old man who consulted us for subacute anxiety, nocturnal hyperhidrosis, severe insomnia, pain in the legs, intermittent diarrhea, and weight loss over 3 months. He had a 15-year history of MG treated with low dose of steroids and mycophenolate. Brain MRI was normal, and the EMG confirmed the presence of neuromyotonia. Serum and CSF studies revealed CRMP5 antibodies concurrent with an unknown antibody that strongly reacted with the membrane of live neurons, making it a good candidate to precipitate the target antigen (see the section "Immunologic Studies"). An MRI of the chest showed an anterior mediastinal mass consistent with thymoma that was surgically removed. He was further treated with steroids and IV immunoglogulin with good response.

Thirteen (30\%) of the 43 patients developed other types of encephalitis: (1) 6 patients had clinical and MRI features of limbic encephalitis with AMPAR antibodies in 4 (1 patient with concurrent CASPR2 and $G A B A_{B} R$ antibodies), LGI1 antibodies in 1 , and absence of antibodies in serum and CSF in the other patient (Figure 1). Compared with other types of encephalitis, the response to immunotherapy was worse. One patient died, and the rest of the patients had mild to moderate cognitive and behavioral sequelae despite immunotherapy. (2) Four patients presented with clinical features of PERM associated with GlyR antibodies in 3 and AMPAR antibodies in 1. (3) Three patients developed clinical manifestations suggestive of encephalitis (confusion, short-term memory loss, and fluctuating level of consciousness), but the brain MRI was normal; all 3 had AMPAR antibodies, with concurrent $G_{A B A} R$ antibodies in 1 .

The functional outcome of patients according to the mRS score at the last follow-up is represented in Figure 3. Patients with anti-GABA $\mathrm{A}_{\mathrm{A}} \mathrm{R}$ encephalitis $(13 / 15,87 \%)$ and those with PERM with GlyR antibodies $(3 / 3,100 \%)$ were more likely to 


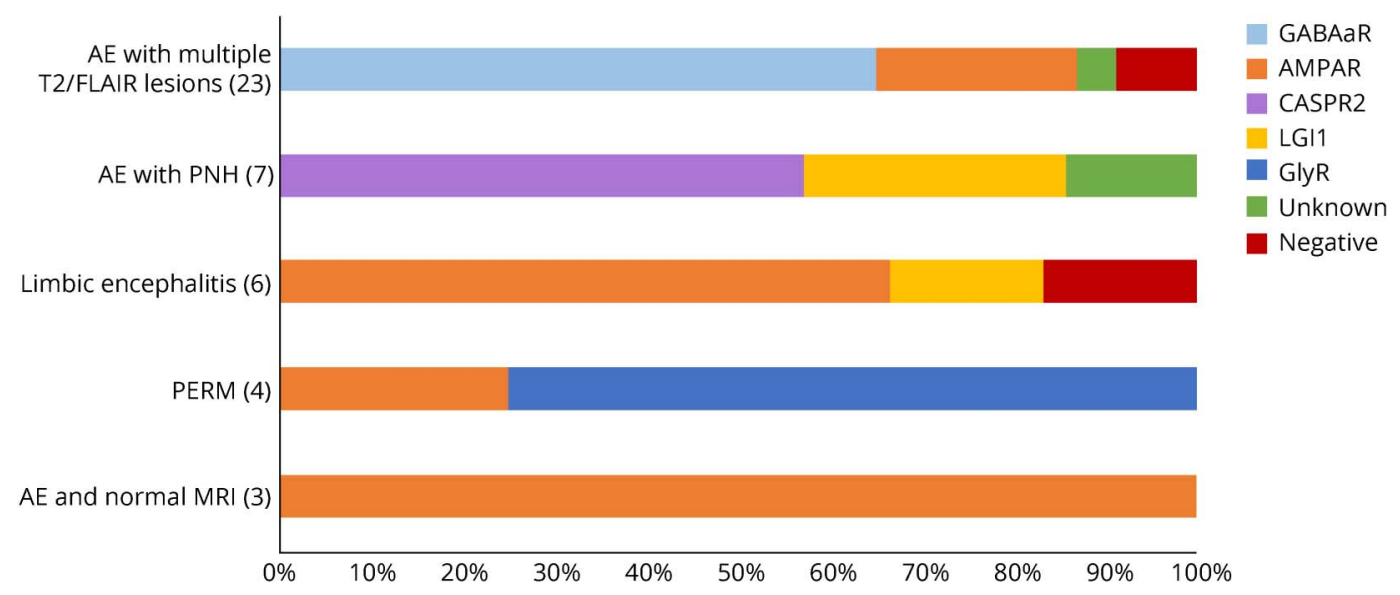

Results are expressed as percentage of each antibody. AE = autoimmune encephalitis; AMPAR = amino-3-hydroxy-5-methyl-4-isoxazolepropionic acid receptor; CASPR2 = contactin-associated protein-like 2; FLAIR = fluid-attenuated inversion recovery; GABA $A$ = gamma-aminobutyric acid receptor A; GlyR = glycine receptor; LGI1 = leucine-rich glioma inactivated 1; PERM = progressive encephalomyelitis with rigidity and myoclonus; PNH = peripheral nerve hyperexcitability.

have good outcome than patients with other antibodyassociated encephalitis $(9 / 21,43 \% ; p=0.019)$. In patients with AMPAR antibodies, the presence of CRMP5 antibodies associated with poor outcome. Three of the 4 patients who did not respond to immunotherapy, but none of the 6 who responded, had concurrent CRMP5 antibodies $(p=0.033)$.

\section{Immunologic Studies}

Immunoprecipitation of granular cells of the cerebellum incubated with serum of the indicated patients with encephalitis and $\mathrm{PNH}$ revealed 16 unique peptides encompassing $22 \%$ of the sequence of rat mGluR3 protein. A CBA using HEK293 cells transfected with mGluR3 (Figure e-1, links.lww.com/NXI/ A517) identified 5 additional patients: 2 with encephalitis and $\mathrm{GABA}_{\mathrm{A}} \mathrm{R}$ or AMPAR antibodies and 3 with isolated neuromuscular disorders. Immunoabsorption studies showed that samples preabsorbed with HEK293-mGluR3 cells abolished the reactivity with mGluR3 expressed in HEK293 cells but did not abrogate the reactivity with rat brain sections, indicating that the neuropil reactivity was due to another unknown antibody.

We next compared the antibody repertoire in thymoma patients with and without $A E$ (Table 2). GABA $A_{A} R$ and AMPAR antibodies were only detected in patients with $\mathrm{AE}$, whereas LGI1 and CASPR2 antibodies were also positive in patients with isolated PNH. Onconeural antibodies, mainly CRMP5, were significantly more common in the encephalitis group $(10 / 43,23 \%)$ but they were also detected in $2(5 \%)$ of 39 thymoma patients without encephalitis $(p=0.028)$ (Table 2).

\section{Discussion}

This retrospective observational study shows that the AE of patients with thymoma ${ }^{8}$ is not a single entity, but a heterogeneous group of encephalitides with different clinical-radiologic features and outcomes that vary according to the associated neuronal surface antibodies. Patients with thymoma with $\mathrm{AE}$ shared 3 clinical characteristics independently of the immunologic subgroup: (1) up to $30 \%$ had a previous diagnosis of MG, (2) the thymoma was locally invasive or metastatic in $51 \%$ and preceded the diagnosis of encephalitis in $37 \%$, and (3) multiple coexisting neuronal antibodies were detected in $40 \%$ of patients, whereas only $7 \%$ were neuronal antibody negative.

Although the first reports on patients with $\mathrm{AE}$ associated with thymoma indicated that they had limbic encephalitis, subsequent single case reports showed that some of them had multiple T2/FLAIR MRI abnormalities beyond the temporal lobes. ${ }^{8,26-28}$ Our study confirms these observations and shows that the MRI findings frequently suggested the antibody that was going to be detected; for example, most patients with multiple T2/FLAIR lesions had $\mathrm{GABA}_{\mathrm{A}} \mathrm{R}$ antibodies and less frequently AMPAR, whereas most cases with limbic encephalitis had AMPAR followed by LGI1 antibodies. In addition, patients with AE and PNH had normal MRI and CASPR2 antibodies.

We found that the most common $\mathrm{AE}$ in patients with thymoma was associated with $\mathrm{GABA}_{\mathrm{A}} \mathrm{R}$ antibodies. The association of anti-GABA $A_{A} R$ encephalitis with thymoma was already recognized in the initial report of this disease and several subsequent case reports from Japan. ${ }^{22,23,29}$ Moreover, in a series of 17 patients with anti-GABA $\mathrm{R}$ encephalitis, the 3 patients with thymoma were also Japanese. ${ }^{20}$ Thus, our study confirms the frequent association of anti-GABA $\mathrm{R}$ encephalitis in Japanese patients with thymoma, as 11 (73\%) of 15 patients with this disorder were Japanese. The reason for this association is unclear but probably indicates a particular genetic susceptibility. For 

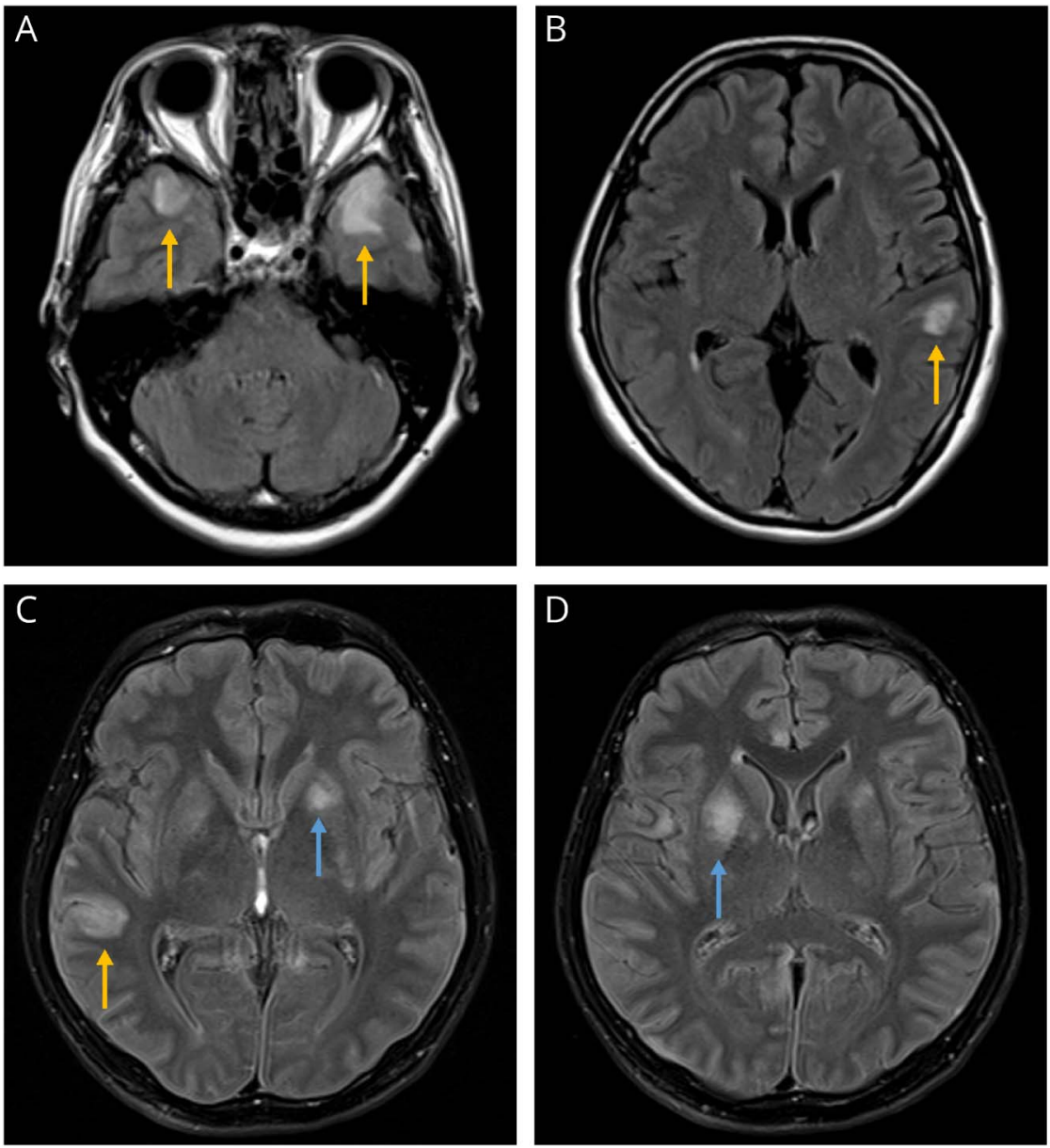

(A and $B$ ) Brain MRI of a patient with anti-GABA ${ }_{A}$ encephalitis. Axial fluid-attenuated inversion recovery images show bilateral hyperintense lesions in temporal lobes (yellow arrows). No lesions are observed in the basal ganglia. (C and D) Brain MR of a patient with anti-AMPAR encephalitis shows hyperintense lesions in the striatum (blue arrows) and another lesion in the temporal lobe (yellow arrow). AMPAR = amino-3-hydroxy-5-methyl-4isoxazolepropionic acid receptor; $\mathrm{GABA}_{\mathrm{A}} \mathrm{R}=$ gamma-aminobutyric acid receptor $\mathrm{A}$. example, the human leukocyte antigen (HLA) class II $\mathrm{DPB} 1^{*} 0501$ allele is associated with susceptibility to the opticospinal form of multiple sclerosis, which is prevalent in Japan but unusual in Western countries. ${ }^{30}$

The anti-GABA $\mathrm{A}$ encephalitis of patients in the current study is otherwise similar to that of patients without thymoma. $^{20,31}$ However, we identified cases with thymoma that developed mild clinical manifestations and spontaneous remission of the brain MRI lesions without immunotherapy. These unusual benign courses should not prevent early onset of treatment as patients may potentially have severe relapses. $^{22}$

AMPAR antibodies were the second most frequent autoantibodies in this series, and the brain MRI findings were heterogeneous. The most common MRI finding was the presence of multiple FLAIR/T2 hyperintense lesions that, unlike anti$\mathrm{GABA}_{\mathrm{A}} \mathrm{R}$ encephalitis, frequently involved the basal ganglia; less frequently, patients had medial temporal lobe FLAIR changes typical of limbic encephalitis. Three patients had normal brain MRI, a feature previously described in cases with or without thymoma. ${ }^{19,32}$ The relative higher frequency (38\%) of multifocal T2/FLAIR lesions in patients with anti-AMPAR encephalitis was not observed in previous series of patients with this disease but without thymoma ( $28 \%$ combining 2 previous series $^{19,33}$ ).

The clinical outcome in patients with anti-AMPAR encephalitis was worse than that of anti-GABA $\mathrm{A}$ encephalitis. This is likely related to the frequent presence of concurrent paraneoplastic antibodies and associated mechanisms, particularly CRMP5 autoimmunity. ${ }^{34,35}$ In a series of 22 patients with anti-AMPAR encephalitis not focused on thymoma, a shorter survival was observed in patients with concurrent onconeural antibodies compared with those harboring isolated AMPAR antibodies. ${ }^{19}$

Although previous studies have shown that patients with encephalitis, PNH, and CASPR2 or LGI1 antibodies usually respond to immunotherapy, ${ }^{36,37}$ we found that this was the group with the worse outcome. There are preliminary data suggesting that the outcome is worse if patients have thymoma. ${ }^{36}$ In a series of 29 patients with Morvan syndrome, the clinical outcome was substantially better in the 17 patients without thymoma. ${ }^{13}$ In contrast, the presence of thymoma did not affect the prognosis of patients with other antibody-related syndromes; for example, the 


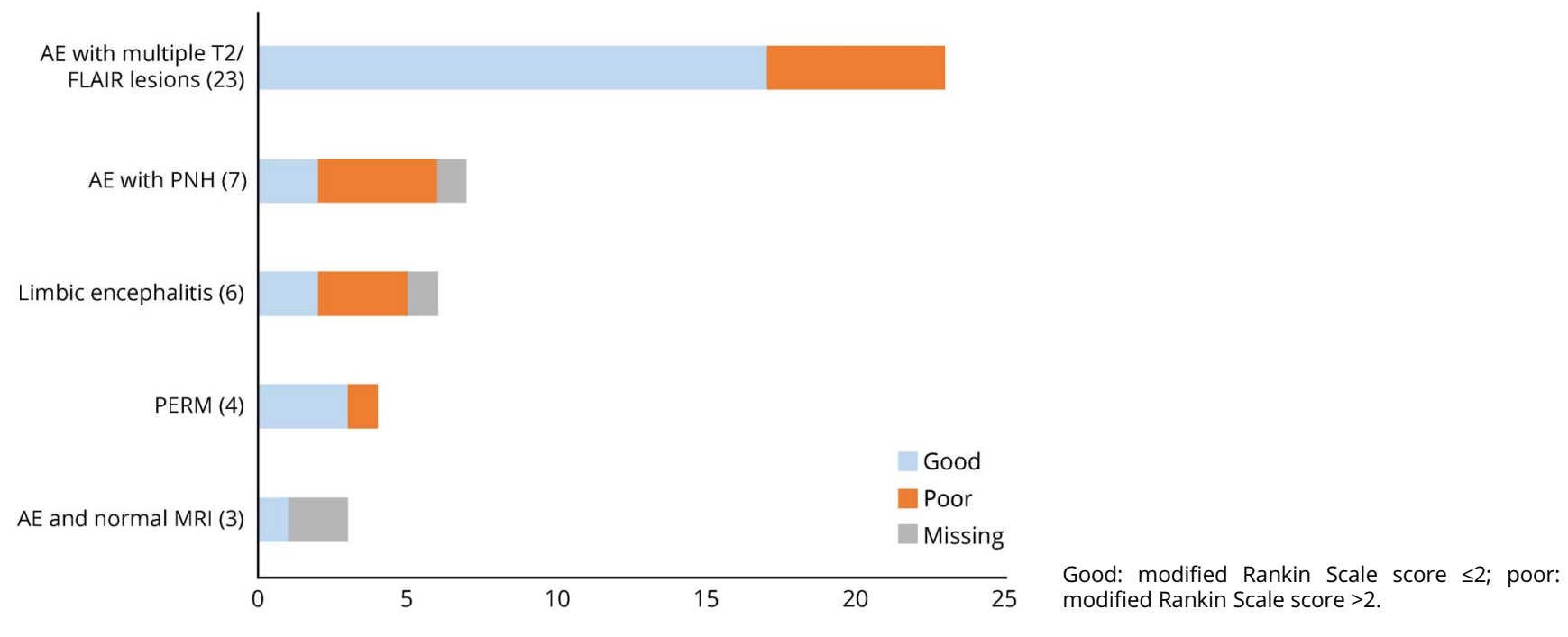

3 patients with PERM and GlyR antibodies made an excellent recovery similar to that observed in idiopathic cases and in 6 of 7 previously reported patients with thymoma. 14,24,38

Using the serum of a patient with encephalitis, $\mathrm{PNH}$, and an unknown neuropil antibody, we precipitated mGluR3. The CBA identified mGluR3 antibodies in 5 additional patients with and without $\mathrm{AE}$ suggesting that the antibodies are biomarkers of the underlying thymoma, rather than the $\mathrm{AE}$, as occur for antibodies against Netrin-1 receptors. ${ }^{39}$ Moreover, the persistence of serum immunoreactivity with the rat brain after immunoabsorption with mGluR3 suggests the presence of additional (not yet characterized) antibodies, emphasizing the frequency of multiple autoantibodies in patients with encephalitis and thymoma.

A limitation of this study is that it is retrospective and may suggest a referral bias for testing some antibodies that are not readily available in commercial antibody panels, such as $\mathrm{GABA}_{\mathrm{A}} \mathrm{R}$ antibodies. However, this potential bias does not explain the association with the Japanese ethnicity observed here because samples from Japan were not sent to our laboratory to specifically confirm the presence of $\mathrm{GABA}_{\mathrm{A}} \mathrm{R}$ antibodies. Brain MRIs were not centrally reviewed, and the data were obtained from radiologic reports preventing an accurate analysis of potentially distinctive MRI features of encephalitis associated with different antibodies.

Our findings have several clinical implications: (1) most patients with thymoma and $\mathrm{AE}$ have neuronal surface autoantibodies that can occur alone or with concurrent intracellular antibodies. (2) Symptoms may occur without CSF pleocytosis, which is common in anti-GABA $A_{A} R$ encephalitis, or with normal brain MRI findings as in some patients with AMPAR or CASPR2 antibodies. (3) Characterization of these antibodies is important because they associate with different syndromes and prognosis. (4) Patients whose serum and CSF are negative for autoantibodies included in clinical or commercial panels, or cases in which the antibody identified does not match with the clinical-radiologic syndrome should have a more comprehensive antibody evaluation. Future studies should include HLA

Table 2 Frequency of Neuronal Antibodies in Patients With Thymoma With and Without Encephalitis

\begin{tabular}{llll}
\hline Antibody & $\begin{array}{l}\text { Encephalitis } \\
(\mathbf{N}=\mathbf{4 3}), \mathbf{n}(\%)\end{array}$ & $\begin{array}{l}\text { No encephalitis } \\
(\mathbf{N}=\mathbf{3 9}), \mathbf{n}(\%)\end{array}$ & $\boldsymbol{p}$ Value \\
\hline GABA $_{\mathbf{A}} \mathbf{R}$ & $15(34.9)$ & $0(0.0)$ & $<0.001$ \\
\hline AMPAR & $13(30.2)$ & $0(0.0)$ & $<0.001$ \\
\hline LGI1 & $6(14.0)^{\mathrm{a}}$ & $3(7.7)^{\mathrm{e}}$ & n.s. \\
\hline CASPR2 & $5(11.6)^{\mathrm{b}}$ & $3(7.7)^{\mathrm{e}}$ & n.s. \\
\hline GlyR & $3(7.0)$ & $0(0.0)$ & n.s. \\
\hline mGluR3 & $3(7.0)^{\mathrm{c}}$ & $3(7.7)$ & n.s. \\
\hline GABA $_{\mathbf{B}} \mathbf{R}$ & $2(4.7)^{\mathrm{d}}$ & $0(0.0)$ & n.s. \\
\hline AQP4 & $0(0.0)$ & $1(2.6)$ & n.s. \\
\hline GAD & $3(7.0)^{\mathrm{f}}$ & $0(0.0)$ & n.s. \\
\hline Onconeural & $10^{\mathrm{g}}(23.3)$ & $2^{\mathrm{h}}(5.1)$ & 0.028 \\
\hline
\end{tabular}

Abbreviations: AMPAR = amino-3-hydroxy-5-methyl-4-isoxazolepropionic acid receptor; $A Q P 4=$ aquaporin 4; CASPR2 = contactin-associated proteinlike 2; $\mathrm{GAD}=$ glutamic acid decarboxylase; $\mathrm{GABA}_{A} \mathrm{R}$ = gamma-aminobutyric acid receptor $A ; G A B A_{B} R=$ gamma-aminobutyric acid receptor $B ;$ GlyR = glycine receptor; $L G I 1=$ leucine-rich glioma inactivated $1 ; \mathrm{mGluR}=$ metabotropic glutamate receptor; n.s. = not significant.

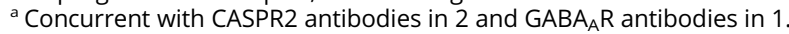

${ }^{\mathrm{b}}$ Concurrent with AMPAR antibodies in 1.

c Concurrent with GABA $\mathrm{CA}_{\mathrm{A}} \mathrm{R}$ antibodies in 1 and AMPAR antibodies in 1.

${ }^{d}$ Concurrent with AMPAR antibodies in 2.

e Patients with peripheral nerve hyperexcitability.

${ }^{f}$ All samples with GAD antibodies showed high antibody levels (defined as $>2,000 \mathrm{IU} / \mathrm{mL}$ by radioimmunoassay).

${ }^{g}$ Nine had CRPM5 and $1 \mathrm{Hu}$ antibodies.

${ }^{\mathrm{h}}$ Two had CRMP5 antibodies. 
genotyping in anti-GABA $\mathrm{R}$ encephalitis to determine any genetic predisposition among Japanese patients with thymoma.

\section{Acknowledgment}

The authors acknowledge José Ríos for providing statistical advice and also thank Maria Rodés, Esther Aguilar, Mercè Alba, and Eva Caballero for their excellent technical work.

\section{Study Funding}

This study was supported in part by Instituto Carlos III (ISCIII, Proyectos Integrados de Excelencia 16/00014, FIS PI20/00197 [J.D.], FIS 18/00067 [L.S.]); ERA-NET NEURON (J.D.); “La Caixa” Foundation (J.D.); Safra Foundation (J.D.); and Fundació Cellex (J.D.). M. Guasp is a recipient of a Resident Award "Josep Font," granted by Hospital Clínic de Barcelona, Research, Innovation and Education Departments. E. Martinez-Hernandez is a recipient of a Juan Rodés grant (JR17/00012) from the Instituto de Salud Carlos III, Madrid, Spain. K. Kaida is a recipient of a grant (JP18K07403) from JSPS KAKENHI. J. Bruna is a recipient of a grant (SLT008/ 18/00028) from the Department of Health of the Generalitat de Catalunya CERCA Program.

\section{Disclosure}

M. Guasp, J. Landa, E. Martinez-Hernandez, and L. Sabater report no disclosures relevant to the manuscript. T. Iizuka received research support from Astellas Pharma Inc. M. Simabukuro, M. Nakamura, M. Kinoshita, M. Kurihara, K. Kaida, J. Bruna, S. Kapetanovic, P. Sánchez, R. Ruiz-García reports, L. Naranjo, J. Planagumà, A. Muñoz-Lopetegi, L. Bataller, and A. Saiz report no disclosures relevant to the manuscript. J. Dalmau holds patents for the use of Ma2, NMDAR, GABAbR, GABAaR, DPPX and IgLON5 as autoantibody tests and receives royalties related to autoantibody tests from Athena Diagnostics and Euroimmun, Inc. F. Graus holds a patent for the use of IgLON5 as an autoantibody test. Go to Neurology.org/NN for full disclosures.

\section{Publication History}

Received by Neurology: Neuroimmunology \& Neuroinflammation March 27, 2021. Accepted in final form May 5, 2021.

Appendix Authors

\begin{tabular}{|c|c|c|}
\hline Name & Location & Contribution \\
\hline $\begin{array}{l}\text { Mar Guasp, } \\
\text { MD }\end{array}$ & $\begin{array}{l}\text { Institut d'Investigacions } \\
\text { Biomèdiques August Pi i } \\
\text { Sunyer (IDIBAPS), Hospital } \\
\text { Clínic, Universitat de } \\
\text { Barcelona, Spain; Neurology } \\
\text { Department, Institute of } \\
\text { Neuroscience, Hospital } \\
\text { Clínic, Barcelona, Spain; } \\
\text { Centro de Investigación } \\
\text { Biomédica en Red, } \\
\text { Enfermedades Raras } \\
\text { (CIBERER), Spain }\end{array}$ & $\begin{array}{l}\text { Drafting/revision of the } \\
\text { manuscript for content, } \\
\text { including medical writing } \\
\text { for content; major role in } \\
\text { the acquisition of data; } \\
\text { study concept or design; } \\
\text { and analysis or } \\
\text { interpretation of data }\end{array}$ \\
\hline
\end{tabular}

\section{Appendix (continued)}

\begin{tabular}{|c|c|c|}
\hline Name & Location & Contribution \\
\hline Jon Landa, MSc & $\begin{array}{l}\text { Institut d'Investigacions } \\
\text { Biomèdiques August Pi i } \\
\text { Sunyer (IDIBAPS), Hospital } \\
\text { Clínic, Universitat de } \\
\text { Barcelona, Spain }\end{array}$ & $\begin{array}{l}\text { Drafting/revision of the } \\
\text { manuscript for content, } \\
\text { including medical writing } \\
\text { for content; major role in } \\
\text { the acquisition of data; } \\
\text { and analysis or } \\
\text { interpretation of data }\end{array}$ \\
\hline $\begin{array}{l}\text { Eugenia } \\
\text { Martinez- } \\
\text { Hernandez, } \\
\text { MD, PhD }\end{array}$ & $\begin{array}{l}\text { Institut d'Investigacions } \\
\text { Biomèdiques August Pi i } \\
\text { Sunyer (IDIBAPS), Hospital } \\
\text { Clínic, Universitat de } \\
\text { Barcelona, Spain; Neurology } \\
\text { Department, Institute of } \\
\text { Neuroscience, Hospital } \\
\text { Clínic, Barcelona, Spain; } \\
\text { Centro de Investigación } \\
\text { Biomédica en Red, } \\
\text { Enfermedades Raras } \\
\text { (CIBERER), Spain }\end{array}$ & $\begin{array}{l}\text { Drafting/revision of the } \\
\text { manuscript for content, } \\
\text { including medical writing } \\
\text { for content, and major } \\
\text { role in the acquisition of } \\
\text { data }\end{array}$ \\
\hline
\end{tabular}

Lidia Sabater, Institut d'Investigacions PhD Biomèdiques August Pi i Sunyer (IDIBAPS), Hospital Clínic, Universitat de Barcelona, Spain; Centro de Investigación Biomédica en Red, Enfermedades Raras (CIBERER), Spain

\begin{tabular}{lll}
\hline Takahiro & Department of Neurology, & Drafting/revision of the \\
lizuka, MD & $\begin{array}{l}\text { Kitasato University School of } \\
\text { Medicine, Sagamihara, Japan }\end{array}$ & $\begin{array}{l}\text { including medical writing } \\
\text { for content, and major } \\
\text { role in the acquisition of } \\
\text { data }\end{array}$ \\
& & \\
&
\end{tabular}

Mateus Neurology Division, Drafting/revision of the
Simabukuro, University of São Paulo, manuscript for content, MD, PhD School of Medicine, Brazil including medical writing for content, and major role in the acquisition of data

\begin{tabular}{ll}
\hline Masataka & Department of Neurology, \\
Nakamura, & Kansai Medical University, \\
MD, PhD & Hirakata, Japan
\end{tabular}
Drafting/revision of the manuscript for content, including medical writing for content, and major role in the acquisition of data

\begin{tabular}{lll}
\hline $\begin{array}{l}\text { Makoto } \begin{array}{l}\text { Kinoshita, MD, } \\
\text { PhD }\end{array} \\
\text { Osaka University Graduate } \\
\text { School of Medicine, Japan }\end{array}$ & $\begin{array}{l}\text { Drafting/revision of the } \\
\text { manuscript for content, } \\
\text { including medical writing } \\
\text { for content, and major role } \\
\text { in the acquisition of data }\end{array}$ \\
\hline $\begin{array}{l}\text { Masanori } \\
\text { Kurihara, MD }\end{array}$ & $\begin{array}{l}\text { Department of Neurology, } \\
\text { Graduate School of } \\
\text { Medicine, University of } \\
\text { Tokyo, Japan }\end{array}$ & $\begin{array}{l}\text { Drafting/revision of the } \\
\text { manuscript for content, } \\
\text { including medical writing } \\
\text { for content, and major role } \\
\text { in the acquisition of data }\end{array}$ \\
\hline $\begin{array}{l}\text { Kenichi Kaida, } \\
\text { MD, PhD }\end{array}$ & $\begin{array}{l}\text { Department of Neurology, } \\
\text { Saitama Medical Center, } \\
\text { Saitama Medical University, } \\
\text { Kawagoe, Japan }\end{array}$ & $\begin{array}{l}\text { Drafting/revision of the } \\
\text { manuscript for content, } \\
\text { including medical writing } \\
\text { for content, and major role } \\
\text { in the acquisition of data }\end{array}$ \\
\hline $\begin{array}{l}\text { Jordi Bruna, } \\
\text { MD, PhD }\end{array}$ & $\begin{array}{l}\text { Neuro-Oncology Unit, } \\
\text { Hospital Universitari de } \\
\text { Bellvitge-ICO L'Hospitalet, } \\
\text { Spain }\end{array}$ & $\begin{array}{l}\text { Drafting/revision of the } \\
\text { manuscript for content, } \\
\text { including medical writing } \\
\text { for content, and major } \\
\text { role in the acquisition of } \\
\text { data }\end{array}$ \\
\hline & &
\end{tabular}


Appendix (continued)

\begin{tabular}{lll}
\hline Name & Location & Contribution \\
\hline $\begin{array}{l}\text { Solange } \\
\text { Kapetanovic, } \\
\text { MD, PhD }\end{array}$ & $\begin{array}{l}\text { Department of Neurology, } \\
\text { Hospital de Basurto, Bilbao, } \\
\text { Spain }\end{array}$ & $\begin{array}{l}\text { Drafting/revision of the } \\
\text { manuscript for content, } \\
\text { including medical writing } \\
\text { for content, and major role } \\
\text { in the acquisition of data }\end{array}$ \\
\hline $\begin{array}{l}\text { Pedro } \\
\text { Sánchez, MD }\end{array}$ & $\begin{array}{l}\text { Hospital Universitario de La } \\
\text { Princesa, Instituto de } \\
\text { Investigación Sanitaria La } \\
\text { Princesa, Madrid, Spain }\end{array}$ & $\begin{array}{l}\text { Drafting/revision of the } \\
\text { manuscript for content, } \\
\text { including medical writing } \\
\text { for content, and major role } \\
\text { in the acquisition of data }\end{array}$
\end{tabular}

Raquel Ruiz- Immunology Department, Drafting/revision of the García, PhD Centre Diagnòstic Biomèdic, manuscript for content Hospital Clínic, Barcelona, including medical writing Spain for content, and major role in the acquisition of data

\begin{tabular}{ll}
\hline Laura Naranjo, & Immunology Department, \\
BSc & Centre Diagnòstic Biomèdic, \\
& Hospital Clínic, Barcelona, \\
& Spain
\end{tabular}

Drafting/revision of the manuscript for content including medical writing for content, and major role in the acquisition of data

\begin{tabular}{ll}
\hline Jesús & Institut d'Investigacions \\
Planagumà, & Biomèdiques August Pi i \\
PhD & Sunyer (IDIBAPS), Hospital \\
& Clínic, Universitat de \\
& Barcelona, Spain
\end{tabular}

Drafting/revision of the manuscript for content, including medical writing for content, and major role in the acquisition of data

\begin{tabular}{lll}
\hline $\begin{array}{l}\text { Amaia Muñoz- } \\
\text { Lopetegi, MD }\end{array}$ & Institut d'Investigacions & Drafting/revision of the \\
Biomeddiques August Pi i & manuscript for content, \\
Clínic, Universitat de & including medical writing \\
Barcelona, Spain; Neurology & for content, and major \\
Department, Institute of & role the acquisition of \\
Neuroscience, Hospital & data \\
Clínic, Barcelona, Spain &
\end{tabular}

\begin{tabular}{ll}
\hline Luis Bataller, & Neurology Department, \\
MD, PhD & Hospital Universitari i \\
& Politècnic La Fe, Valencia, \\
& Spain
\end{tabular}

Drafting/revision of the manuscript for content, including medical writing for content, and major role in the acquisition of data

\begin{tabular}{lll}
\hline Albert Saiz, & Institut d'Investigacions & Drafting/revision of the \\
MD, PhD & Biomèdiques August Pi i & manuscript for content, \\
& Sunyer (IDIBAPS), Hospital & including medical writing \\
& Clínic, Universitat de & for content, and major \\
& Barcelona, Spain; Neurology & role in the acquisition of \\
Department, Institute of & data \\
& Neuroscience, Hospital & \\
Clínic, Barcelona, Spain &
\end{tabular}

Josep Dalmau, Institut d'Investigacions MD, PhD Biomèdiques August Pi i Sunyer (IDIBAPS), Hospital Clínic, Universitat de Barcelona, Spain; Neurology Department, Institute of Neuroscience, Hospital Clínic, Barcelona, Spain; Centro de Investigación Biomédica en Red, Enfermedades Raras (CIBERER), Spain; Department of Neurology, Perelman School of Medicine, University of Pennsylvania, Philadelphia; Catalan Institute for Research and Advanced Studies (ICREA), Barcelona, Spain

\section{Appendix (continued)}

\begin{tabular}{|c|c|c|}
\hline Name & Location & Contribution \\
\hline $\begin{array}{l}\text { Francesc } \\
\text { Graus, MD, } \\
\text { PhD }\end{array}$ & $\begin{array}{l}\text { Institut d'Investigacions } \\
\text { Biomèdiques August Pi i } \\
\text { Sunyer (IDIBAPS), Hospital } \\
\text { Clínic, Universitat de } \\
\text { Barcelona, Spain }\end{array}$ & $\begin{array}{l}\text { Drafting/revision of the } \\
\text { manuscript for content, } \\
\text { including medical writing } \\
\text { for content; study concept } \\
\text { or design; and analysis or } \\
\text { interpretation of data }\end{array}$ \\
\hline
\end{tabular}

\section{References}

1. Evoli A, Lancaster E. Paraneoplastic disorders in thymoma patients. J Thorac Oncol. 2014;9(9 suppl 2):S143-S147.

2. Marx A, Willcox N, Leite MI, et al. Thymoma and paraneoplastic myasthenia gravis. Autoimmunity. 2010;43(5-6):413-427.

3. Marx A, Pfister F, Schalke B, Saruhan-Direskeneli G, Melms A, Ströbel P. The different roles of the thymus in the pathogenesis of the various myasthenia gravis subtypes. Autoimmun Rev. 2013;12(9):875-884.

4. Evoli A, Minicuci GM, Vitaliani R, et al. Paraneoplastic diseases associated with thymoma. J Neurol. 2007;254(6):756-762.

5. Marx A, Muller-Hermelink HK, Strobel P. The role of thymomas in the development of myasthenia gravis. Ann NY Acad Sci. 2003;998:223-236.

6. Darnell RB, Posner JB. Paraneoplastic syndromes involving the nervous system. N Engl J Med. 2003;349(16):1543-1554.

7. McArdle JP, Millingen KS. Limbic encephalitis associated with malignant thymoma. Pathology. 1988;20(3):292-295.

8. Erkmen CP, Fadul CE, Dalmau J, Erkmen K. Thymoma-associated paraneoplastic encephalitis (TAPE): diagnosis and treatment of a potentially fatal condition. J Thorac Cardiovasc Surg. 2011;141(2):e17-e20.

9. Vernino S, Lennon VA. Autoantibody profiles and neurological correlations of thymoma. Clin Cancer Res. 2004;10(21):7270-7275

10. Zekeridou A, McKeon A, Lennon VA. Frequency of synaptic autoantibody accompaniments and neurological manifestations of thymoma. JAMA Neurol. 2016;73(7):853-859.

11. Dalmau J, Geis C, Graus F. Autoantibodies to synaptic receptors and neuronal cell surface proteins in autoimmune diseases of the central nervous system. Physiol Rev. 2017;97(2):839-887.

12. Graus F, Titulaer MJ, Balu R, et al. A clinical approach to diagnosis of autoimmune encephalitis. Lancet Neurol. 2016;15(4):391-404.

13. Irani SR, Pettingill P, Kleopa KA, et al. Morvan syndrome: clinical and serological observations in 29 cases. Ann Neurol. 2012;72(2):241-255.

14. Carvajal-Gonzalez A, Leite MI, Waters P, et al. Glycine receptor antibodies in PERM and related syndromes: characteristics, clinical features and outcomes. Brain. 2014; 137 (pt 8):2178-2192.

15. Ances BM, Vitaliani R, Taylor RA, et al. Treatment-responsive limbic encephalitis identified by neuropil antibodies: MRI and PET correlates. Brain. 2005;128(pt 8): 1764-1777.

16. Graus F, Dalmau J, Valldeoriola F, et al. Immunological characterization of a neuronal antibody (anti-Tr) associated with paraneoplastic cerebellar degeneration and Hodgkin's disease. J Neuroimmunol. 1997;74(1-2):55-61.

17. Landa J, Guasp M, Petit-Pedrol M, et al. Seizure-related 6 homolog like 2 autoimmunity: neurologic syndrome and antibody effects. Neurol Neuroimmunol Neuroinflamm. 2021;8(1):e916.

18. Sabater L, Gaig C, Gelpi E, et al. A novel non-rapid-eye movement and rapid-eyemovement parasomnia with sleep breathing disorder associated with antibodies to IgLON5: a case series, characterisation of the antigen, and post-mortem study. Lancet Neurol. 2014;13(6):575-586.

19. Hoftberger R, vS A, Leypoldt F, et al. Encephalitis and AMPA receptor antibodies: novel findings in a case series of 22 patients. Neurology. 2015;84(24):2403-2412.

20. Spatola M, Petit-Pedrol M, Simabukuro MM, et al. Investigations in GABAA receptor antibody-associated encephalitis. Neurology. 2017;88(11):1012-1020.

21. Omi T, Kinoshita M, Nishikawa A, et al. Clinical relapse of anti-AMPAR encephalitis associated with recurrence of thymoma. Intern Med. 2018;57(7):1011-1013.

22. Kurihara M, Sasaki T, Sakuishi K, et al. Isolated seizure as initial presentation of GABA(A) receptor antibody-associated encephalitis. J Neurol Sci. 2020;410:116666.

23. Kitano T, Kinoshita M, Shimazu K, Fushimi H, Omori K, Hazama T. A case of relapsing encephalitis positive for gamma aminobutyric acid (GABA)(A) receptor antibody associated with Type B3 thymoma [in Japanese]. Rinsho Shinkeigaku. 2016; 56(11):764-768.

24. Morise S, Nakamura M, Morita JI, et al. Thymoma-associated progressive encephalomyelitis with rigidity and myoclonus (PERM) with myasthenia gravis. Intern Med. 2017;56(13):1733-1737.

25. Graus F, Boronat A, Xifro X, et al. The expanding clinical profile of anti-AMPA receptor encephalitis. Neurology. 2010;74(10):857-859.

26. Ingenito GG, Berger JR, David NJ, Norenberg MD. Limbic encephalitis associated with thymoma. Neurology. 1990;40(2):382.

27. Cunningham JD, Burt ME. Limbic encephalitis secondary to malignant thymoma. Ann Thorac Surg. 1994;58(1):250-251. 
28. Antoine JC, Honnorat J, Anterion CT, et al. Limbic encephalitis and immunological perturbations in two patients with thymoma. J Neurol Neurosurg Psychiatry. 1995; 58(6):706-710.

29. Ohkawa T, Satake S, Yokoi N, et al. Identification and characterization of GABA(A) receptor autoantibodies in autoimmune encephalitis. J Neurosci. 2014;34(24): 8151-8163.

30. Fukazawa T, Kikuchi S, Sasaki H, et al. Genomic HLA profiles of MS in Hokkaido, Japan: important role of DPB1*0501 allele. J Neurol. 2000;247(3):175-178.

31. Guo CY, Gelfand JM, Geschwind MD. Anti-gamma-aminobutyric acid receptor type A encephalitis: a review. Curr Opin Neurol. 2020;33(3):372-380.

32. Li X, Mao YT, Wu JJ, Li LX, Chen XJ. Anti-AMPA receptor encephalitis associated with thymomatous myasthenia gravis. J Neuroimmunol. 2015;281:35-37.

33. Joubert B, Kerschen P, Zekeridou A, et al. Clinical spectrum of encephalitis associated with antibodies against the alpha-amino-3-hydroxy-5-methyl-4-isoxazolepropionic acid receptor: case series and review of the literature. JAMA Neurol. 2015;72(10): 1163-1169.
34. Jia Y, Wang J, Xue L, Hou Y. Limbic encephalitis associated with AMPA receptor and CRMP5 antibodies: a case report and literature review. Brain Behav. 2020;10(3): e01528.

35. Yang S, Qin J, Li J, et al. Rapidly progressive neurological deterioration in anti-AMPA receptor encephalitis with additional CRMP5 antibodies. Neurol Sci. 2016;37(11): 1853-1855.

36. Gadoth A, Pittock SJ, Dubey D, et al. Expanded phenotypes and outcomes among 256 LGI1/CASPR2-IgG-positive patients. Ann Neurol. 2017;82(1):79-92.

37. van Sonderen A, Arino H, Petit-Pedrol M, et al. The clinical spectrum of Caspr2 antibody-associated disease. Neurology. 2016;87(5):521-528.

38. Ozaki K, Ohkubo T, Yamada T, et al. Progressive encephalomyelitis with rigidity and myoclonus resolving after thymectomy with subsequent anasarca: an autopsy case. Intern Med. 2018;57(23):3451-3458.

39. Torres-Vega E, Mancheño N, Cebrián-Silla A, et al. Netrin-1 receptor antibodies in thymoma-associated neuromyotonia with myasthenia gravis. Neurology. 2017;88(13): $1235-1242$. 


\title{
Neurology \\ Neuroimmunology \& Neuroinflammation
}

\author{
Thymoma and Autoimmune Encephalitis: Clinical Manifestations and Antibodies \\ Mar Guasp, Jon Landa, Eugenia Martinez-Hernandez, et al. \\ Neurol Neuroimmunol Neuroinflamm 2021;8; \\ DOI 10.1212/NXI.0000000000001053
}

This information is current as of July 23, 2021

\section{Updated Information \& Services}

References

Citations

Subspecialty Collections

Permissions \& Licensing

Reprints including high resolution figures, can be found at: http://nn.neurology.org/content/8/5/e1053.full.html

This article cites 39 articles, 3 of which you can access for free at: http://nn.neurology.org/content/8/5/e1053.full.html\#\#ref-list-1

This article has been cited by 2 HighWire-hosted articles: http://nn.neurology.org/content/8/5/e1053.full.html\#\#otherarticles

This article, along with others on similar topics, appears in the following collection(s):

Autoimmune diseases

http://nn.neurology.org//cgi/collection/autoimmune_diseases Encephalitis

http://nn.neurology.org//cgi/collection/encephalitis

Paraneoplastic syndrome

http://nn.neurology.org//cgi/collection/paraneoplastic_syndrome

Information about reproducing this article in parts (figures,tables) or in its entirety can be found online at:

http://nn.neurology.org/misc/about.xhtml\#permissions

Information about ordering reprints can be found online:

http://nn.neurology.org/misc/addir.xhtml\#reprintsus

Neurol Neuroimmunol Neuroinflamm is an official journal of the American Academy of Neurology.

Published since April 2014, it is an open-access, online-only, continuous publication journal. Copyright

Copyright (C) 2021 The Author(s). Published by Wolters Kluwer Health, Inc. on behalf of the American

Academy of Neurology.. All rights reserved. Online ISSN: 2332-7812.

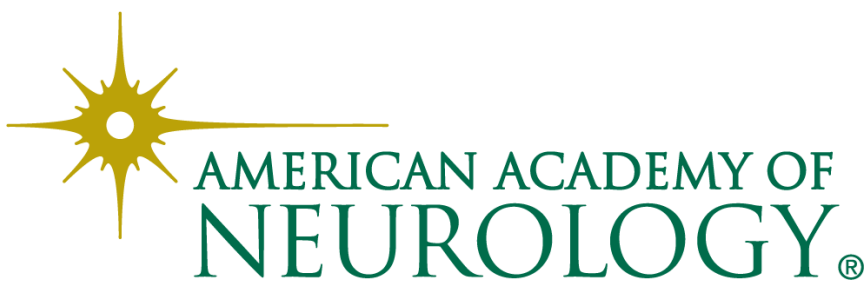

